\title{
Persepsi Guru Mengenai Pentingnya TIK dalam Pembelajaran di Taman Kanak-Kanak Kota Pontianak
}

\author{
Desni Yuniarni ${ }^{\bowtie}$ \\ Pendidikan Guru Pendidikan Anak Usia Dini, Universitas Tanjungpura, Indonesia \\ DOI: $\underline{10.31004 / \text { obsesi.v6i3.1855 }}$
}

\begin{abstract}
Abstrak
Masih banyak guru yang belum dapat memanfaatkan Teknologi, Informasi dan Komunikasi (TIK) dalam pembelajaran di Taman Kanak-kanak (TK). Tujuan dari penelitian ini adalah untuk mengetahui bagaimana persepsi guru mengenai pentingnya TIK dalam perencanaan, pelaksanaan dan evaluasi pembelajaran di TK di kota Pontianak melalui metode deskriptif dalam bentuk penelitian survei dengan menggunakan alat ukur kuesioner yang diberikan kepada guru TK yang ada di kota Pontianak. Pendekatan penelitian yang digunakan dalam penelitian ini adalah pendekatan kuantitatif. Data dianalisis dengan menggunakan teknik analisis deskriptif persentase. Teknik pengambilan sampel yang digunakan adalah simple random sampling, yaitu sebanyak 676 orang guru TK di kota Pontianak. Hasil penelitian menunjukkan sebanyak 75\% guru-guru TK di kota Pontianak menyatakan pentingnya TIK dalam merencanakan pembelajaran. Sebanyak 85\% guru-guru TK di kota Pontianak menyatakan bahwa TIK memiliki peran yang sangat penting dalam melaksanakan pembelajaran dan sebanyak $96 \%$ guru TK di kota Pontianak menyatakan bahwa TIK sangat penting dalam mengevaluasi pembelajaran.
\end{abstract}

Kata Kunci: teknologi informasi dan komunikasi; taman kanak-kanak, persepsi guru

\begin{abstract}
There are still many teachers who have not been able to utilize Technology, Information and Communication (ICT) in learning in Kindergarten (TK). The purpose of this study was to find out how teachers perceive the importance of ICT in planning, implementing and evaluating learning in kindergarten in Pontianak city through a descriptive method in the form of survey research using a questionnaire measuring instrument given to kindergarten teachers in Pontianak city. The research approach used in this study is a quantitative approach. Data were analyzed using descriptive percentage analysis technique. The sampling technique used is simple random sampling, as many as 676 kindergarten teachers in the city of Pontianak. The results showed that $75 \%$ of kindergarten teachers in the city of Pontianak stated the importance of ICT in planning learning. As many as $85 \%$ of kindergarten teachers in the city of Pontianak stated that ICT had a very important role in implementing learning and as many as $96 \%$ of kindergarten teachers in the city of Pontianak stated that ICT was very important in evaluating learning.
\end{abstract}

Keywords: ict; kindergarten, teacher perception

Copyright (c) 2022 Anita Damayanti, et al.

$\triangle$ Corresponding author:

Email Address : anita.damayanti@umj.ac.id (Jakarta, Indonesia)

Received 11 August 2021, Accepted 12 November 2021, Published 17 January 2022

Jurnal Obsesi : Jurnal Pendidikan Anak Usia Dini, 6(3), 2022 | 2411 


\section{PENDAHULUAN}

Keberadaan Teknologi, Informasi dan Komunukasi (TIK) dewasa ini sudah tidak dapat lagi dipisahkan dalam setiap aspek kehidupan kita, begitu juga dalam bidang pendidikan. Adanya TIK dapat mempermudah tugas guru dan meningkatkan kualitas dalam pembelajaran.

Meningkatnya kualitas pembelajaran diperoleh dari meningkatnya kemampuan guru dalam merencanakan, melaksanakan dan melakukan penilaian terhadap proses pembelajaran (Riyadi, 2017). Guru yang dapat merencanakan, melaksanakan dan melakukan penilaian terhadap proses pembelajaran adalah guru yang memiliki kompetensi professional. Kompetensi professional yang dimiliki oleh guru, mengarah pada kemampuan guru merencanakan pembelajaran, menerapkan pembelajaran sesuai dengan perencanaan, melakukan penilaian dan evaluasi pembelajaran (Sufiati \& Afifah, 2019). Adanya TIK dapat meningkatkan kompetensi professional seorang guru. Guru yang professional adalah guru yang memiliki kemampuan untuk dapat mengaplikasikan TIK dalam merancang pembelajaran yang menarik, melaksanakan pembelajaran yang dapat meningkatkan minat anak dalam belajar dan dapat melakukan evaluasi belajar secara proporsional untuk meningkatkan kualitas pembelajaran yang telah dilakukannya.

Menurut Hasbi et al. (2020), manfaat TIK bagi guru PAUD adalah mengatasi keterbatasan pengalaman, melampaui batasan ruang kelas, interaksi langsung dengan lingkungan, memberikan pengalaman dan perspektif yang benar, meningkatkan efektivitas dan efisiensi pembelajaran. Sejalan dengan itu, Susanto (2017) menyatakan bahwa pemanfaatan TIK dalam proses pembelajaran perlu dirancang, direncanakan, dilaksanakan dan selalu dievaluasi dari waktu ke waktu agar pemanfaatan TIK dalam pembelajaran PAUD dapat benar-benar maksimal dari segi dukungannya pada pelaksanaan fungsi dan tercapainya tujuan dalam rangka menyiapkan generasi bangsa yang cerdas dan ceria, perlu mengoptimalkan kemanfaatannya dan menimalkan dampak negatifnya.

Pendapat diatas, sejalan dengan yang dikemukakan oleh Widyawati (2019) yaitu guru perlu lebih banyak berperan sebagai fasilisator siswa dalam belajar, mengintegrasikan alatalat teknologi ke dalam pembelajaran untuk mendukung pelaksanaan pengajaran dan pembelajaran, dimana teknologi digunakan sebagai alat untuk secara aktif mendukung tugastugas pengajaran dan pembelajaran. Dengan demikian, dapat disimpulkan bahwa guru dapat menggunakan teknologi dalam pembelajaran untuk mendukung tugasnya dalam mengajar. Kesimpulan tersebut sejalan dengan hasil penelitian Febrialismanto (2020) yang menyatakan bahwa terdapat perbedaan antara guru TK yang menggunakan TIK dalam pembelajaran dengan yang tidak menggunakan TIK, dimana guru yang menggunakan TIK dalam pembelajaran dapat lebih meningkatkan perkembangan anak dan memiliki kualitas yang lebih baik dalam proses pembelajaran dibandingkan dengan guru yang tidak menggunakan TIK dalam pembelajaran.

Berdasarkan pendapat beberapa diatas, dapat disimpulkan bahwa TIK sangat bermanfaat dalam pembelajaran di TK. Dengan adanya TIK, guru dapat merancang, melaksanakan dan mengevaluasi pembelajarang di PAUD dengan lebih baik lagi. TIK juga dapat meningkatkan efektifitas dan efisiensi dalam pembelajaran. Adanya TIK membuat pembelajaran yang diberikan kepada anak usia dini menjadi lebih menarik, berkesan dan mendukung tugas-tugas pengajaran dan pembelajaran.

Namun, pada kenyataannya, guru lebih sering memberikan pembelajaran yang bersifat monoton, berfokus pada baca dan tulis dan belum menggunakan teknologi sebagai salah satu media yang digunakan dalam pembelajaran (Nisa', 2020). Menurut Hardiyana (2016) rendahnya kualitas pembelajaran di PAUD, diantaranya adalah belum optimalnya kemampuan guru dalam memanfaatkan teknologi informasi dan komunikasi yang bisa diaplikasikan dalam pembelajaran PAUD di sekolah.

Lebih jauh lagi, hasil penelitian dari Susanti (2020) menunjukkan bahwa teknologi belum banyak dimanfaatkan secara maksimal oleh guru, dimana banyak pendidik belum 
dapat memanfaatkan teknologi sebagai media pembelajaran. Sejalan dengan hal tersebut, penelitian yang dilakukan oleh Sugiarti et al., (2019) menunjukkan bahwa rendahnya kompetensi pedagogik dan kompetensi profesional yang dikuasai oleh guru PAUD berkorelasi dengan tingkat pendidikan yang sebagian besar masih lulusan SLTA, oleh karena itu perlu diupayakan peningkatan kompetensi di luar pendidikan formal, yaitu dengan memanfaatkan Teknologi Informasi dan Komunikasi (TIK), dimana pemanfaatan TIK yang semula hanya untuk komunikasi dan hiburan saja di ubah menjadi pemanfaatan TIK untuk mendukung peningkatan kompetensinya

Melalui pembudayaaan memanfaatkan web sebagai sumber belajar dengan di akses melalui berbagai produk teknologi informasi dan komunikasi untuk keperluan pendidikan.

Berdasarkan fenomena diatas, peneliti ingin mengetahui bagaimana persepsi para guru TK yang ada di kota Pontianak mengenai pentingnya TIK dalam pembelajaran di TKnya. Hal tersebut dikarenakan meningkatkan penggunaan TIK di kalangan masyarakat luas dewasa ini terutama oleh para guru TK, banyaknya referensi yang menyebutkan pentingnya TIK dalam pembelajaran di TK dan lebih jauh lagi ingin mengetahui bagaimana persepsi para guru TK di kota Pontianak mengenai pemanfaatan TIK di TKnya, mengingat penelitian mengenai hal tersebut belum ada di lakukan di kota Pontianak.

Temuan pra penelitian, melalui metode interview yang peneliti lakukan kepada 5 orang guru TK swasta dan 5 orang guru TK negeri yang ada di kota Pontianak, menunjukkan bahwa guru-guru TK tersebut, belum memanfaatkan TIK dalam merancang/merencanakan, melaksanakan dan mengevaluasi pembelajaran. Oleh karena itu dalam penelitian ini, peneliti ingin mengetahui bagaimana persepsi guru mengenai pentingnya TIK dalam pembelajaran di TK Kota Pontianak.

Secara rinci permasalahan khusus dalam penelitian ini adalah bagaimana persepsi guru mengenai pentingnya TIK dalam perencanaan pembelajaran di TK Kota Pontianak, bagaimana persepsi guru mengenai pentingnya TIK dalam pelaksanaan pembelajaran di TK Kota Pontianak, bagaimana persepsi guru mengenai pentingnya TIK dalam evaluasi pembelajaran di TK Kota Pontianak.

\section{METODOLOGI}

Pendekatan penelitian yang digunakan dalam penelitian ini adalah pendekatan kuantitatif. Data dianalisis dengan menggunakan teknik analisis deskriptif persentase. Lokasi dalam melakukan penelitian survei ini TK swasta/negeri di kota Pontianak yang berjumlah 143 TK (Sumber : Dinas Pendidikan Prov. Kalbar diolah oleh Diskominfo Prov. Kalbar tahun 2020-2021). Sumber data yang dimaksud dalam penelitian ini adalah guru-guru TK Negeri dan Swasta di kota Pontianak, sudah sertifikasi, merupakan guru kelas dan memiliki latar belakang S1 PG-PAUD.

Berdasarkan karakteristik tersebut peneliti mendapatkan data populasi sebanyak 676 orang pendidik Taman Kanak-kanak yang ada di Kota Pontianak. Jumlah sampel yang diambil adalah sampel dengan menggunakan tingkat kepercayaan 99\%. Penentuan tingkat kepercayaan ini merupakan tingkat kepercayaan yang sering digunakan dalam penelitian. Jumlah sampel yang diambil dengan tingkat kepercayaan 99\% adalah sebanyak 634 orang.

Teknik pengambilan sampel yang digunakan adalah simple random sampling, dimana tiap anggota diberikan kesempatan yang sama untuk terpilih menjadi sampel. Prosedur yang digunakan dalam teknik simple random sampling. Metode sampling ini dipilih karena memiliki margin of error lebih kecil dan varian lebih kecil dilihat dari efisiensi relatifnya. Menduga parameter menggunakan inferensi statistik untuk mendapatkan penduga parameter yang tidak bias dan konsisten (Kish \& Frankel, 1974). Selain itu juga dapat memenuhi presisi dalam menduga parameter agar sesuai dengan parameter populasi (Elsayir, 2014). 
Penduga parameter untuk simple random sampling diukur dari mean dan variannya. Mean populasi $(\mu)$ adalah jumlah rata-rata per unit sampel dengan mean sampel $(\hat{\mu}$ atau $\bar{y})$ yang memiliki estimator tidak bias sebagai berikut:

$$
\hat{\mu}=\frac{\sum_{i=1}^{n} y_{i}}{n}
$$

Dimana $y i$ merupakan nilai tiap unit sample dan $\mathrm{n}$ merupakan jumlah unit pada sampel. Sedangkan varian populasi $(\sigma 2)$ dilakukan estimasi dengan varian sampel sebagai berikut:

$$
s^{2}=\frac{\sum_{i=1}^{n}\left(y_{i}-\bar{y}\right)^{2}}{n-1}
$$

Dengan varian dari $\hat{\mu}$ adalah sebagai berikut:

$$
\operatorname{vâr}(\hat{\mu})=\left(\frac{N-n}{N}\right) \frac{s^{2}}{n}
$$

Nilai penduga parameter berupa nilai mean dan varians dijelaskan pada Tabel 1.

Tabel 1. Penduga Parameter pada Simple Random Sampling

\begin{tabular}{cc}
\hline Penduga Parameter & 634 \\
Mean & 22,45 \\
Varian & 0,002 \\
\hline
\end{tabular}

Dari Tabel 1 akan dilakukan penghitungan margin of error untuk mendeskripsikan bahwa jumlah sampel berpengaruh pada besarnya margin of error. Jumlah sampel yang besar menjadikan margin of error suatu sampling akan menjadi kecil dan berlaku sebaliknya

Data hasil survei sangat memungkinkan terjadi kesalahan (error). Kesalahan dalam pengambilan sampel ini sering disebut dengan Margin of Error. Indikator Margin of Error (MoE) merupakan nilai untuk mengukur seberapa besar sampel yang diambil mampu mewakili (merepresentasikan) populasi (Arieska \& Herdiani, 2018).

Pada pengambilan sampel sebanyak 634 sampel (yaitu dengan tingkat kepercayaan 99\%), MoE yang diperoleh besarnya 0,005 menunjukkan bahwa jumlah sampel yang diambil dapat mewakili populasi yang ada.

Selanjutnya, proses perekrutan subyek penelitian dilakukan secara langsung dengan mendatangi satu-persatu guru TK yang ada di kota Pontianak yang berjumlah 634 orang. alat pengumpul data yang digunakan dalam penelitian ini adalah kuesioner. Sebelum pengisian kuesioner akan dilakukan persetujuan penelitian (informed consent). Melalui persetujuan penelitian, peneliti akan mendeskripsikan penelitian yang dilakukan dan meminta persetujuan dari responden. Kuesioner ini disusun sendiri oleh peneliti. Sebelum digunakan, kuesioner ini telah diuji validitas dan reliabilitasnya. Uji validitas yang digunakan adalah uji validitas konstruksi. Validitas konstruk dilakukan oleh validator. Validator pada penelitian ini adalah dosen PG-PAUD. Hasil dari uji validitas konstruk pada kuesioner ini adalah, kuesioner ini dapat digunakan dengan perbaikan pada beberapa redaksi kalimatnya. Perbaikan redaksi kalimat tersebut sudah dilakukan dan kuesioner dinyatakan valid untuk digunakan. Selanjutnya untuk mengukur tingkat kepercayaan atau seberapa dapat diandalkannya kuesioner yang telah divalidasi menjadi alat ukur dalam penelitian ini, dilakukan uji reliabilitas instrument menggunakan rumus Alpha Cronbach. Kuesioner yang telah disusun Reliabilitas angket telah diuji dengan menggunakan uji Cronbach's Alpha 
Persepsi Guru Mengenai Pentingnya TIK dalam Pembelajaran di Taman Kanak-Kanak Kota Pontianak

DOI: 10.31004/obsesi.v6i3.1868

dengan hasil koofesien (r) 0.836. Karena koefisien reliabilitasnya diatas 0.700 , maka angket ini dapat dikatakan reliabel.

Analisis yang digunakan dalam penelitian ini yaitu analisis deskriptif persentase karena data hasil penelitian berupa angka-angka dan dideskripsikan berbentuk persentase. Untuk melihat bagaimana persepsi guru terhadap pentingnya TIK dalam merencanakan, melaksanakan dan mengevaluasi pembelajaran di TK Kota Pontianak, maka peneliti menggunakan acuan kriteria penafsiran data menurut Arikunto (dalam (Qoma et al., 2016) sebagaimana ditunjukkan pada tabel 2.

Tabel 2. Kriteria Penafsiran Data

\begin{tabular}{cc}
\hline Persentase & Kriteria \\
$81 \%-100 \%$ & Sangat Penting \\
$61 \%-80 \%$ & Penting \\
$41 \%-60 \%$ & Cukup Penting \\
$21 \%-40 \%$ & Kurang Penting \\
$0 \%-20 \%$ & Tidak Penting \\
\hline
\end{tabular}

\section{HASIL DAN PEMBAHASAN}

Persepsi guru mengenai pentingnya TIK dalam perencanaan pembelajaran di TK Kota Pontianak

Pada tabel 3 menunjukkan sebanyak 75\% guru-guru TK di kota Pontianak menyatakan bahwa TIK memiliki peran yang penting dalam merencanakan pembelajaran. Hal ini dikarenakan guru memerlukan TIK dalam merencanakan tujuan pembelajaran, materi pembelajaran, metode pembelajaraan, sumber belajar, kegiatan pembelajaran (kegiatan awal, inti, dan penutup), media pembelajaran, alat dan bahan pembelajaran, dan bagaimana merancang penilaian/evaluasi pembelajaran yang nantinya akan dilakukan, yang tentunya harus disesuaikan dengan tema yang telah ditetapkan.

Adanya TIK dapat menambah informasi, memperkaya wawasan dan meningkatkan kreatifitas guru dalam merencanakan serangkaian kegiatan pembelajaran untuk anak didiknya yang sesuai dengan tema. Tema dalam pembelajaran berfungsi untuk mengembangkan seluruh potensi anak dengan seluruh aspek perkembangannya. Oleh karena itu pemilihan tujuan pembelajaran, materi pembelajaran, metode pembelajaraan, sumber belajar, kegiatan pembelajaran (kegiatan awal, inti, dan penutup), media pembelajaran, alat dan bahan pembelajaran, dan bagaimana merancang penilaian/evaluasi pembelajaran harus sesuai tema pembelajaran.

Tabel 3. Persentase persepsi guru mengenai pentingnya TIK dalam perencanaan pembelajaran di TK Kota Pontianak

\begin{tabular}{cc}
\hline Persentase Guru & \multicolumn{1}{c}{ Persepsi Guru } \\
\hline $75 \%$ & TIK berperan penting dalam perencanaan pembelajaran \\
$25 \%$ & TIK berperan kurang penting dalam perencanaan pembelajaran \\
\hline
\end{tabular}

Hal tersebut sejalan dengan pendapat Pamungkas et al., (2016) yang menyatakan bahwa tema berfungsi sebagai wadah yang berisi bahan kegiatan untuk mengembangkan potensi anak dan menyatukan seluruh kompetensi dalam satu kesatuan yang lebih berarti, memperkaya wawasan dan perbendaharaan kata anak sehingga pembelajaran menjadi lebih bermakna. Dimana, adanya TIK dapat meningkatkan akurasi informasi, meningkatkan efisiensi waktu, menambah relevansi informasi yang diperoleh dan mendapatkan manfaat yang lebih banyak dalam merencakan pembelajaran dibandingkan jika tidak menggunakan TIK (Istiyarti \& Khristiyanta, 2014). 
Selain itu, TIK dapat membantu guru dalam memperoleh informasi dalam lingkup yang luas dari berbagai sumber melalui cyber space atau ruang maya dengan menggunakan komputer atau internet (Gunawan, 2013). Hal tersebut sejalan dengan hasil penelitian Lestari et al. (2020) yang menggambarkan bahwa perencanaan pembelajaran pada pendidikan anak usia dini yang disusun melalui suatu sistem informasi berbasis website dalam bentuk website perencanaan pembelajaran akan saling berkaitan antar tampilan dan memudahkan para guru dalam membuat perencanaan yang saling berkaitan, saling berhubungan antara satu tema ke tema pembelajaran lainnya.

Berdasarkan berbagai pendapat tersebut, terlihat jelas bahwa TIK memiliki peran yang penting bagi guru dalam merencanakan pembelajarannya. Sedangkan 25\% guru perlu menyatakan bahwa TIK memiliki peran yang kurang penting dalam merencanakan pembelajaran. Hal ini dikarenakan keterbatasan kemampuan para guru tersebut dalam menggunakan TIK. Menurut Upitasari (2020) kendala yang mencegah guru menggunakan TIK dalam pengajaran mereka adalah kurangnya kepercayaan diri. Selain itu juga, ketidakmampuan guru dalam memanfaatkan komputer dan internet sebagai media pembelajaran (Sahelatua et al., 2018) juga menjadi alasan guru menyatakan bahwa TIK memiliki peran kurang penting dalam perencanaan pembelajaran. Alasan lainnya dikarenakan rendahnya kompetensi guru dalam mengoperasikan TIK (Andriani et al., 2021). Oleh karena itu, dapat disimpulkan bahwa pernyataan guru yang menganggap bahwa TIK kurang memiliki peran yang penting dalam merencanakan pembelajaran dikarenakan keterbatasan guru, rendahnya kompetensi dan rendahnya kepercayaan diri guru dalam menggunakan TIK tersebut untuk membuat perencanaan pembelajaran di TK nya.

\section{Persepsi guru mengenai pentingnya TIK dalam pelaksanaan pembelajaran di TK Kota Pontianak}

Dari tabel 4 dapat dilihat sebanyak $85 \%$ guru-guru TK di kota Pontianak menyatakan bahwa TIK memiliki peran yang sangat penting dalam melaksanakan pembelajaran. Hal ini sejalan dg pendapat Fadlillah (2018) yang menyatakan bahwa pada saat pembelajaran, pendidik harus menggunakan berbagai pendekatan, strategi, dan metode pembelajaran untuk mencapai tujuan pembelajaran yang ditentukan. Variasi terhadap berbagai pendekatan, strategi dan metode pembelajaran tersebut dapat diperoleh melalui TIK. Pelaksanaan pembelajaran pendidikan anak usia dini menurut Permendiknas No 58 Tahun 2009 (dalam (Ridho et al., 2017) dilakukan dengan (1) penataan lingkungan bermain, dan (2) pengorganisasian kegiatan meliputi: (a) pembukaan (b) kegiatan inti, dan (c) penutup. Dalam hal ini pemanfaat TIK secara arif, berperan penting sebagai dalam penataan lingkungan bermain dan pengorganisasian kegiatan (kegiatan pembukaan, inti dan penutup) kegiatan pembelajaran di TK.

Tabel 4. Persentase persepsi guru mengenai pentingnya TIK dalam pelaksanaan pembelajaran di TK Kota Pontianak

\begin{tabular}{cc}
\hline Persentase Guru & Persepsi Guru \\
\hline $85 \%$ & TIK berperan sangat penting dalam pelaksanaan pembelajaran \\
$15 \%$ & TIK berperan kurang penting dalam pelaksanaan pembelajaran \\
\hline
\end{tabular}

Hal ini seperti yang disampaikan oleh Siahaan (2015), dimana pemanfaatan TIK secara arif (terencana, terpadu dan teratur) memfasilitasi kegiatan pembelajaran. Memfasilitasi kegiatan artinya: (1) memberikan kemudahan bagi guru dalam membelajarkan peserta didiknya; (2) menjadikan uraian berbagai objek yang bersifat abstrak menjadi konkrit; (3) memvisualisasikan secara animatif tahapan-tahapan suatu proses atau siklus; juga (4) meningkatkan efisiensi penggunaan waktu oleh guru untuk menyelenggarakan kegiatan pembelajaran termasuk pemberian berbagai penjelasan. Salah satu contoh penggunaan TIK dalam pelaksanaan pembelajaran di TK adalah hasil penelitian yang disampaikan oleh 
Nukman et al. (2022) yaitu terdapat peningkatan kecerdasan verbal linguistik anak usia dini melalui pemanfaatan media TIK yang berbentuk media Tik Tok. Dengan fiturnya yang beragam dan kemudahan dalam pengoperasian, maka pemanfaatan aplikasi Tik Tok dapat diimplemtasikan dalam pembelajaran dialog antara guru dan peserta didik.

Dapat disimpulkan, bahwa TIK memiliki peran yang sangat penting dalam pelaksanaan pembelajaran di TK, karena dengan adanya TIK, pendidik dapat memberikan variasi terhadap berbagai pendekatan, strategi dan metode pembelajaran. Selain itu juga, TIK dapat memberikan kemudahan, menjadikan objek pembelajaran lebih kongkrit, memvisualisasikan tahapan pembelajaran serta meningkatkan efisiensi pembelajaran.

Sedangkan $15 \%$ guru perlu menyatakan bahwa TIK memiliki peran yang kurang penting dalam melaksanakan pembelajaran. Hal tersebut dikarenakan adanya beberapa hambatan yang dialami guru yang berkaitan dengan pengaplikasian TIK dalam pembelajaran, dimana hasil penelitian Styaningrum (2016) menyatakan bahwa hambatan yang dihadapi guru dalam mengaplikasikan teknologi diantaranya adalah terbatasnya fasilitas pribadi yang dimiliki guru tersebut, kemampuan guru yang terbatas dalam menggunakan teknologi, umur yang bertambah tua, dan keterbatasan waktu yang dimiliki untuk mempelajari dan mempraktekkan teknologi itu sendiri. Hal tersebut tersebut sejalan dengan hasil penelitian Yusuf et al. (2021) yang menyatakan bahwa hambatan yang dirasakan guru berkaitan dengan TIK dalam pembelajaran adalah guru belum dapat memaksimalkan manfaat TIK untuk kegiatan pelaksanaan pembelajaran, sehingga TIK belum dapat berfungsi optimal dalam pembelajaran yang mereka laksanakan.

Berdasarkan hal tersebut, dapat disimpulkan bahwa, kurang pentingnya peran TIK dalam pelaksanaan pembelajaran di TK disebabkan karena para guru TK tersebut memiliki keterbatasan dalam ketersediaan fasilitas pribadi untuk dapat mengoperasikan TK, kemampuan guru yang terbatas dalam menggunakan teknologi, umur yang bertambah tua, dan keterbatasan waktu yang dimiliki untuk mempelajari dan mempraktekkan teknologi itu sendiri serta guru belum dapat memaksimalkan manfaat TIK untuk kegiatan pelaksanaan pembelajaran di TKnya.

\section{Persepsi guru mengenai pentingnya TIK dalam evaluasi pembelajaran di TK Kota Pontianak}

Sebanyak 96\% para guru-guru di TK kota Pontianak menyatakan bahwa TIK memiliki peran yang sangat penting dalam evaluasi pembelajaran. Hal ini sejalan dengan pendapat Jatmiko et al. (2020), dimana dalam evaluasi pembelajaran terdapat bagian-bagian dari evaluasi, yaitu merumuskan atau menetapkan kegiatan, menyiapkan alat atau teknik penilaian, menetapkan kriteria penilaian, menentukan nilai dan mengumpulkan data. Agar bagian-bagian dari evaluasi tersebut dapat terlaksana dengan baik, diperlukan aplikasi TIK untuk memudahkan guru melaksanakan bagian-bagian dari evaluasi pembelajaran tersebut.

Hanya $4 \%$ guru yang menganggap TIK kurang penting dalam evaluasi pembelajaran. Hal ini disebabkan belum meratanya infrastuktur yang mendukung penerapan TIK di bidang pendidikan merupakan permasalahan awal yang harus segera diselesaikan oleh pihak yang berwenang, karena tanpa adanya infrastruktur yang mendukung maka penerapan TIK di bidang pendidikan hanya akan menjadi impian semata (Sawitri et al., 2019).

\section{SIMPULAN}

Berdasarkan hasil penelitian, diperoleh kesimpulan secara umum sebagian besar guruguru di kota Pontianak menyatakan bahwa TIK memiliki peran yang sangat penting bagi perencanaan, pelaksanaan dan evaluasi pembelajaran di TK. Hal ini dikarenakan TIK memiliki banyak manfaat dan keuntungan yang diperoleh sehingga dengan menggunakan TIK guru dapat terbantu dalam perencanaan, pelaksanaan dan evaluasi pembelajarannya di TK. 


\section{UCAPAN TERIMA KASIH}

Ucapan terimakasih kami sampaikan kepada semua pihak yang telah berkontribusi dalam penelitian ini, khususnya kepada para guru-guru TK Negeri dan Swasta di Kota Pontianak dan semua pihak yang tidak bisa disebutkan satu persatu.

\section{DAFTAR PUSTAKA}

Andriani, R., Andriany, D. A., \& Lailia, S. K. (2021). Meningkatkan Kualitas Guru Dalam Menguasai TIK Melalui Program Microsoft Partner in Learning (PiL) dan Aplikasi Moodle. Conference Series Journal, 01(01), 1-6.

Arieska, P. K., \& Herdiani, N. (2018). Pemilihan Teknik Sampling Berdasarkan Perhitungan $\begin{array}{llll}\text { Efisiensi Relatif. Jurnal 6(2), 166-171. } & \text { Stistika, }\end{array}$ https://jurnal.unimus.ac.id/index.php/statistik/article/view/4322/ 4001

Fadlillah, M. (2018). Pelaksanaan Pembelajaran Berbasis Kurikulum 2013 Di Tk It Qurrota a'Yun Babadan Ponorogo. Early Childhood: Jurnal Pendidikan, 2(1), 47-58. https:// doi.org/10.35568/earlychildhood.v2i1.200

Febrialismanto. (2020). Perbedaan Kemampuan Guru Menggunakan TIK Untuk Pengembangan Anak Usia Dini. Jurnal Obsesi : Jurnal Pendidikan Anak Usia Dini, 5(2), 1603-1615. https://doi.org/10.31004/obsesi.v5i2.743

Gunawan, Z. (2013). Pemanfaatan Teknologi Informasi dan Komunikasi (TIK) Dalam Pembelajaran. Jurnal Ilmiah Pendidikan Fisika: Al Biruni, 3(1), 61-69. https:// doi.org/10.24042/jpifalbiruni.v3i1.67

Hardiyana, A. (2016). Optimalisasi Pemanfaatan Teknologi Informasi Dan Komunikasi Dalam Pembelajaran Paud. Awlady:Jurnal Pendidikan Anak, 1-12.

Hasbi, M., Fridani, L., Wahyuningsih, S., Wahyuni, M., \& Rakhmawati, E. T. (2017). Pemanfaatan ICT (Informations And Communication Technologies) Dalam Pembelajaran Anak Usia Dini. Tarbawy: Jurnal Pendidikan Islam, 4(2). https:// doi.org/10.32923/tarbawy.v4i2.820

Istiyarti, N., \& Khristiyanta, E. P. (2014). Pemanfaatan Tik Untuk Pembelajaran. Jurnal Kwangsan, 2(1), 63. https://doi.org/10.31800/jurnalkwangsan.v2i1.15

Jatmiko, A. J., Hadiati, E. H., \& Oktavia, M. O. (2020). Penerapan Evaluasi Pembelajaran Anak Usia Dini di Taman Kanak-kanan. Al-Athfaal: Jurnal Ilmiah Pendidikan Anak Usia Dini, 3(1), 83-97. https://doi.org/10.24042/ajipaud.v3i1.6875

Lestari, R. H., Sumitra, A., Nurunnisa, R., \& Fitriawati, M. (2020). Perancangan Perencanaan Pembelajaran Anak Usia Dini Melalui Sistem Informasi Berbasis Website. Jurnal Obsesi : Jurnal Pendidikan Anak Usia Dini, 5(2), 1396-1408. https:// doi.org/10.31004/obsesi.v5i2.770

Nisa', L. (2020). Pemanfaatan Teknologi Dalam Pendidikan Anak Usia Dini. Thufula: Jurnal Inovasi Pendidikan Guru Raudhatul Athfal, 001. https:// doi.org/10.21043/thufula.v8i1.6283

Nukman, A., Rahmawati, I., Zubaidi, A., Yatin, A., \& Dewi, H. R. (2022). Improving Verbal Linguistic Intelligence in Early Childhood Through the Use of Tiktok Media. 6(3), 23162324. https://doi.org/10.31004/obsesi.v6i3.2083

Pamungkas, J., Hayati, N., \& Maryatun, I. B. (2016). Pengembangan Perencanaan Pembelajaran Paud Berbasis Budaya. Jurnal Pendidikan Anak, 5(2), 831-839. https://doi.org/10.21831/jpa.v5i2.12389

Qoma, D. I., Risyak, B., \& Surahman, M. (2016). Persepsi Guru Dalam Mengelola Ruang Kelas PAUD. Jurnal Pendidikan Anak, 2(July), 1-23. http://jurnal.fkip.unila.ac.id/index.php/PAUD/article/view/11595/8258

Ridho, R., Markhamah, \& Darsinah. (2017). Pengelolaan Pembelajaran Pendidikan Anak Usia Dini (PAUD) DI KB "CERDAS" Kecamatan Sukorejo Kabupaten Kendal. Jurnal Penelitian Humaniora, 5(02), 59-69. 
Riyadi, S., \& Mulyapradana, A. (2017). Pengaruh Motivasi Kerja Terhadap Kinerja Guru Radhatul Atfal di Kota Pekalongan. Jurnal Litbang Kota Pekalongan, 13.

Sahelatua, Vitoria, L., \& Mislinawat. (2018). Kendala Guru Memanfaatkan Media It Dalam Pembelajaran Di Sdn 1 Pagar Air Aceh Besar. Ilmiah Pendidikan Guru Sekolah Dasar, 3(2), 131-140. http://www.jim.unsyiah.ac.id/pgsd/article/download/8579/3601

Sawitri, E., Astiti, M. S., \& Fitriani, Y. (2019). Hambatan Dan Tantangan Pembelajaran Berbasis Teknologi Informasi Dan Komunikasi. Prosiding Seminar Nasional Pendidikan Program Pascasarjana Universitas PGRI Palembang, 202-213.

Siahaan, S. (2015). Pemanfaatan Teknologi Informasi Dan Komunikasi Dalam Pembelajaran: Peluang, Tantangan, Dan Harapan. Jurnal Teknodik, 321-332. https://doi.org/10.32550/teknodik.v19i3.173

Styaningrum, A. (2016). Analisis Hambatan Guru Dalam Pengintegrasian Teknologi Di Smpn 1 Grabag. 702011130.

Sufiati, V., \& Afifah, S. N. (2019). Peran perencanaan pembelajaran untuk performance mengajar guru pendidikan anak usia dini. Jurnal Pendidikan Anak, 8(1), 48-53. https://doi.org/10.21831/jpa.v8i1.26609

Sugiarti, Y., Maman, U., \& Ratnawati, S. (2019). Implementasi Tik Dalam Meningkatkan Kompetensi Guru Paud Melalui Knowledge Management System Implementation of Ict in Improving Early Childhoud Education (Ece) Teacher Competence Through Knowledge Management System. Jurnal Teknodik, 043-052. https://doi.org/10.32550/teknodik.v17i4.576

Susanti, S. S. (2020). Pemanfaatan Teknologi Dalam Pendidikan Anak Usia Dini. AZZAHRA, II $(1)$.

Susanto, A. (2017). Pemanfaatan ICT (Informations and Communication Technologies) dalam Pembelajaran Anak Usia Dini. Tarbawy: Jurnal Pendidikan Islam, 4(2), 230-241. https:// doi.org/10.32923/tarbawy.v4i2.820

Upitasari, R. (2020). Hambatan penggunaan tik dalam pembelajaran. Lentera: Jurnal Diklat Keagamaan Padang, 4(2), 50-59.

Widyawati. (2019). Integrasi Teknologi Informasi Dalam Pembelajaran Anak Usia Dini. Ya Bunayya, 1(1), 16-28. https:// doi.org/10.35473/ijec.v1i1.133

Yusuf, F., Prastyo, S., \& Amnah. (2021). Analisis Hambatan Penggunaan Teknologi Informasi dan Komunikasi (TIK) dalam Pembelajaran Matematika SMK. Jurnal Ilmiah Mahasiswa Matematika, 1(1), 28-32. 